\title{
【特＼cjkstart集：エコデザイン】
}

\section{IT 社会のエコデザイン}

藤 本 淳 ${ }^{*}$

【要 旨】安全で豊かな低カーボン（二酸化炭素排出が少ない）社会のビジョンをわかりやすい形で提 示し，実現に向けた道筋を具体化することは，持続可能社会形成への貢献，および社会に活力を与える 点で重要である。ここでは，エコデザインの新しい概念を提唱し，その適用例として“IT 社会の環境 調和設計”の取組みを紹介する。ここで提唱するエコデザインとは，環境・経済面からの定量評価を ベースに（ファクトファインディングとベンチマーク），目的指向のトップダウンアプローチと，従来 の技術指向型ボトムアップアプローチとを適切に融合することで，製造・生産技術，ビジネスモデル， そして社会システムまでを，環境と経済の両面より最適化し，新たな付加価値の創造を目指すすのであ る。この概念を用いて,「循環型 IT 社会」の設計図を示す。

キーワード：エコデザイン, IT, トップダウンアプローチ, 地球温暖化対策, エコライフ

\section{1. 環境への対応}

環境・エネルギー分野は, 21 世紀の社会や生活を抜 本的に变革し, 停滞している需要の拡大をもたらす可能 性が高い領域,さらにわが国が世界的にみて相応の強み を有しており，国際市場での競争力の源泉となる領域と して選択された 4 つの重点分野の一つに揭げられている (産業発掘戦略)。そこでは「メイドインジャパン」を “環境ブランド”として国際的に定着させ，産業競争力 強化につなげること等を目指している。

現状の企業における活動は，社会・市場二ーズへの対 応に追われている。環境問題の原因や対策の必要性が科 学的に明らかになる前の段階でも, マスメディア報道に よって市民の “リスク回避”の意識が高まり，市場二ー ズが形成されれば対応せざるを得ない。製造やマーケッ トデータの取得が容易である点, 製品を製造し市場で販 売する点で，大学に比較して有利な立場にあり，環境負 荷評価および環境規制に対応した技術開発等で，活動の 主体となっている。しかし，活動の成果としては，売上

原稿受付 2004.3. 25

* 東京大学先端科学技術研究センター

連絡先 : ₹ 153-8904 東京都目黒区駒場 4-6-1

E-mail : junf@su.rcast.u-tokyo.ac.jp
げ増加などには程遠く，企業イメージの向上などの間接 的なあのが多いのが現状であろう。環境が企業の競争力 強化や新しいビジネス創生につながる “期待感”はある が，それを具現化すべき戦略的な取組みにそしく，独創 的なビジネスモデル創出には至っていない。

一方, 大学において屯, 環境問題への取組みは活発化 している。大学で “環境”と名の付く学部, 学科, 講座 は急增しており, 理系・文系合せて, 学部が約 30 , 学 科で約 170, 講座では約 700 存在する（2002 年現在）。 しかしその内容は，あらゆる技術（または制度）が直接 あるいは間接的に環境問題に関係するという領域の広さ を反映して多様であり, 従来の専門領域の看板の書換え のようなものも多い。環境研究とは何か，すなわち従来 の専門領域で取組むべき課題と，環境研究として取組む べき課題が明確化されていないため，混沌とした状態に ある。独創的ビジネスモデルの創出につながる将来の環 境調和型社会の具体像の明確化や，環境による経済活性 化を支える人材の育成が急務の課題となっている。

\section{2. エコデザインの概念}

環境活動の方向を 2 つの軸で整理した（図 1 ）。横軸 は，活動のトリガーとなる環境問題の把握について，科 学的に裏づけされたものとマスメディア主導による感覚 


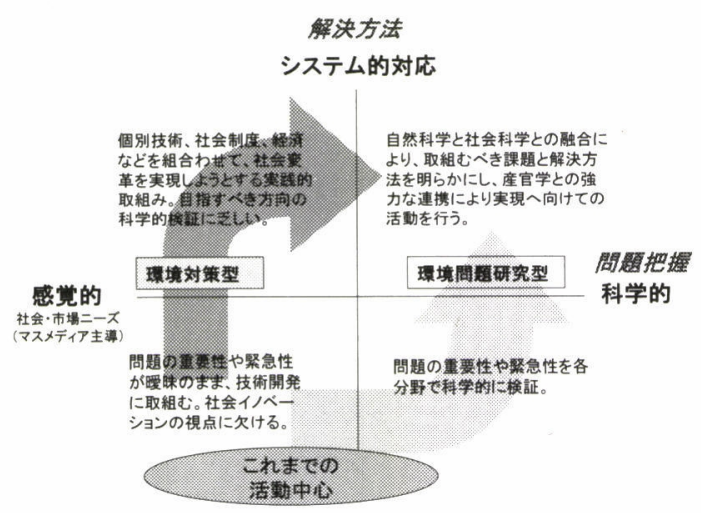

個別技術主体

図 1 環境活動の方向

的なむのに, 縦軸は, 解決の方法で, 個別技術開発を主 体としたものと，システム的対応（技術・制度・教育な どの要素の適切な組合せ）とにそれぞれ分類した。現状， 企業や大学での活動の主体は，感覚的（部分的）に捉元 られた課題に対する個別技術を主体とした対応だといえ る。これを最終的な目標である, 科学的に問題が実証さ れ原因が究明された問題の合理的（システム的手段）な 解決へ向かうには，2つの道筋がある。実践的な活動を 通して行うものと (環境対策型), 科学的検証を中心し た活動（環境問題研究型）である。環境対策型は，社会 ニーズに沿って, 循環社会形成や地球温暖化防止などに 関連する技術・システム開発を行う実践的活動である。 社会ニーズの妥当性, すなわち「優先的に取組む課題か 否か」等が不明確であることが多く，技術開発の効辝性 という観点では問題があるが，環境対策のスピードおよ び産業界での活動支援という点では重要である。環境問 題研究型は, 提起された問題の信憑性, 緊急性, 原因の 解明，および合理的解決方法の模索を行う活動である。 社会ニーズの妥当性や環境対策型に打ける技術開発の有 効性の検証や，今後進むべき方向性を提示する役割を果 たす。エコデザインは，環境対策型の活動である。

現状，“エコデザイン”といえば，家電製品，情報機 器，自動車などの製品を対象とした“環境配慮活動”を 表すことが多い。これらは, 製品の環境性能を従来に比 較して“改善”するあので, 図 1 の縱軸でいえば, 個別 技術での対応である。これらを，社会の環境負荷削减に より有効につなげるには，広い視点から対象を捉元，い ろいろな手段を適切に融合して対処する“システム的な 対応”が必要となる。図 2 は, “低カロリーピザ（仮 想)”を例に，これまでのエコデザインの取組みの問題 点を説明したものである。社会の人々のダイエットを目 的に，“低カロリーピザ (対策技術)”を開発した。これ

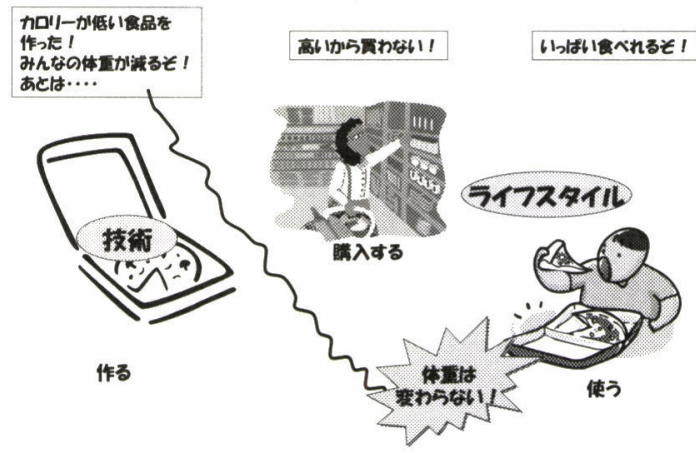

図2 低カロリーピザの開発

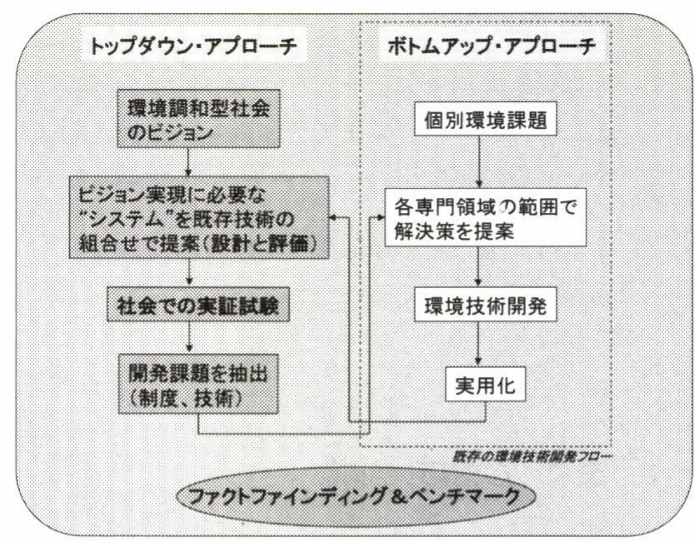

図 3 エコデザインの概念

で，ダイエットに貢献したといえるであろうか？ ダイ エットに結びっくには, 多くの人々に低力ロリーピザを 選択してもらわなければならない（普及の問題）。さら に, 低力ロリーだからといって, 食事量が増えればか えってマイナスとなる（波及の影響）。また従来，他の 低カロリー食品をとっていた人が，低カロリーピザに乗 りかえれば，社会全体のダイエットにはつながらないで あろう (波及の影響)。この例から明らかなように，環 境対策を効率的に社会の負荷削隇につなげるには，個別 の技術開発だけでなく，技術が利用されるライフスタイ ルや社会全体を俯㒈し，全体を環境・経済面より最適化 する取組みが必要となる。

著者が考えるエコデザインの概念を図 3 にまとめた。 環境・経済面からの定量評価をべースに（ファクトファ インディングとベンチマーク), 目的志向のトップダウ ンアプローチと（目指すべく社会のビジョンを明確にし， それを実現するために必要な社会システムやライフス夕 イルを既存の技術をべースに設計した後，社会での実証 試験を通してシステムの有効性や新たに改良や開発が必 要となる社会制度，技術，ビジネスモデル等を明らかに 
する)，従来の技術指向型ボトムアップアプローチとを 適切に融合することで, 製造・生産技術, ビジネスモデ ル，そして社会システムまでを，環境亡経済の両面より 最適化し, 新たな付加価值の創造を目指すものである1)。 ここでは，エコデザインの概念による “IT（Information Technology) 社会の環境調和設計”の取組みを紹 介する。

\section{3. エコデザインのIT 社会への応用}

高機能なモノを安く大量に生産し販売する産業, モノ やエネルギの大量消費というライフスタイルを追求する 市民・消費者, この構図の上で環境問題の一つ一つの症 状に対症療法的治療を施しても, 環境・経済の両面で大 きな成果を得られない。疾病の原因である産業活動やラ イフスタイルを, より環境負荷の小さい形態に変革する 原因治療的な対応が今まさに必要である。

通信ネットワークと情報処理の技術発展と, それらの 技術の融合により, 社会生活のあらゆる場面で新たな可 能性を獲得するに至った。産業では, 資材調達, 物流, およびオフィス業務の效率化, ビジネスのグローバル化 等である。日常生活では, 趣味や娛楽での情報獲得, 人 とのコミュニケーション手段, 抢よび商品の購入等の方 法が大きく変わりつつある。これらの変化は, 今後の予 想される通信の高速化/大容量化 (ブロードバンド化) や, コネクション手段の多様化や容易化（ユビキタス 化）に伴い,さらに加速すると考えられる。社会構造の 大变革である (IT 革命)。資源・エネルギーの消費形態 は, 社会構造に立脚したものであることを考えると, IT 革命により, 資源・エネルギー消費の形態は大きく 変化し, 環境へ少なくない影響を与えることが予想され る。IT 革命へ向けて動き出した現在, IT 普及の方向を 社会の環境負荷低減につながるように設計することで (IT 社会のエコデザイン), 産業活動やライフスタイル を環境調和的に変革する “原因治療”に貢献できるので はないか, というのがこの研究の視点である。

\section{IT の環境影響とエコデザイン体系}

IT の環境影響については，プラス・マイナスの両面 が考えられる（図4）。マイナス面（環境負荷の増大） は, IT 機器の生産/運用/廃棄で消費される資源・エ ネルギーや, 廃製品の増加である。また, IT 化により生 み出された経斎的・時間的余裕は, 新たな経済活動を生 み，資源・エネルギー消費の増加をもたらすことも懸念 されている (リバウンド効果)。一方, IT 化がもたらす

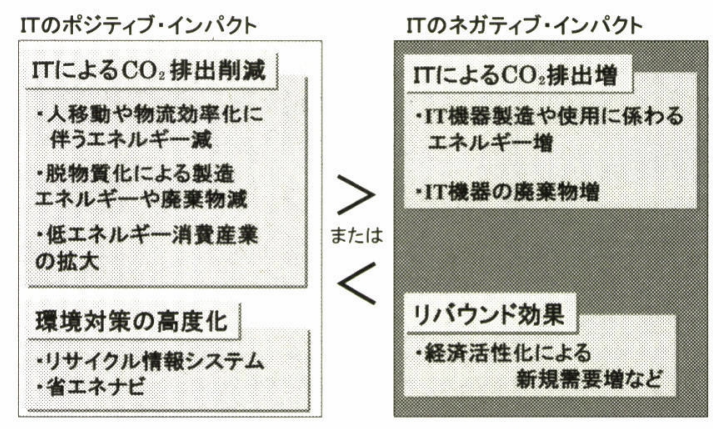

図 4 IT の環境影響

プラス効果では, 人・モノの移動や生産における部材調 達の効率化等による資源・エネルギー消費の削減, 産業 構造の変化（低エネルギー消費産業の拡大）があげられ る。さらに環境対策に，IT を活用することで，対策の高 度化や効率化が図られ, 環境負荷削減が促進されること あ期待される。このプラス効果を, マイナス影響よりも 大きなものにすることが，エコデザインの目的となる。

IT 社会のエコデザイン体系を図 5 に示す。エコデザ インの対象を大きく 4 つに分類する。

1 ）ネットワーク/インターフェースの環境負荷

IT 機器普及に伴うエネルギー消費量の増大や廃棄物 量増加への対策を実施する。

2 ）環境配慮アプリケーション

製品循環システム, 省エネルギー対策などに, IT を 積極的に活用し，対策の高度化や効率化を実現する。ま た, 誘発効果による環境負荷増加の抑制や, 環境対策の 普及を目的としたIT の活用方法も考えられる。たとえ ば, 社会生活のあらゆる場面で環境に関連する情報を生 活者に提示し, 生活者の環境配虑行動を促進するシステ ム等が,これに相当する。

3 ) 社会基盤アプリケーション

電子書籍・新聞やソフト・音楽のオンライン配信など による情報媒体の削減, テレビ会議や $\mathrm{e}-$-ラーニングに よる人移動の削減, SCM に上る生産効率化, インター ネットショッピングに物品販売の効率化, ITSによる 人・物移動の効率化など, IT 化による資源・エネル ギー消費削減の可能性が指摘されている。これらの評 価・分析，および削減ポテンシャルを最大化するための 普及および活用方法を研究する。

\section{4 ）環境調和型 IT 社会}

前記 1) 〜 3) 項を総合して, IT の普及により実現 できる“低環境負荷社会のビジョン”を提示し, 評価分 析する。また, 社会での実証試験（IT グリーンコミュ ニティ形成）を介して，資源・エネルギー消費の検証や 市場性の評価を行い，必要な技術開発項目を明確化する。 


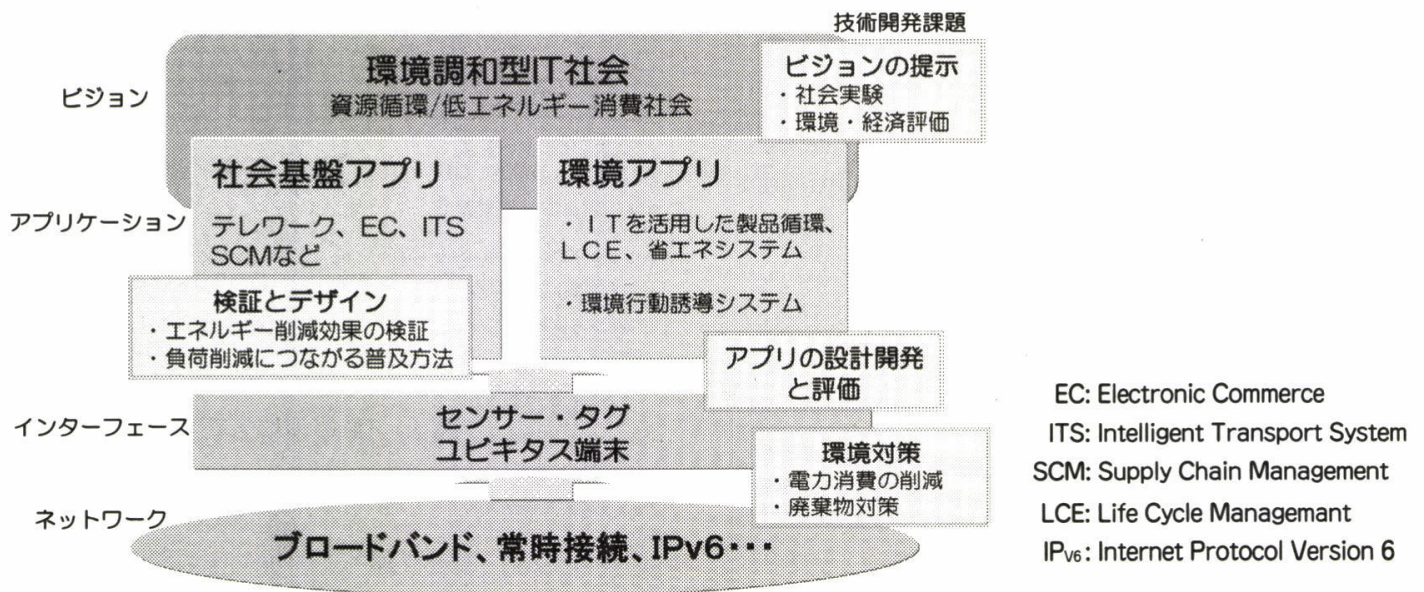

図 5 IT 社会のエコデザイン大系

以下の章では, 各項目の内容について概説する。

\section{5. ネットワーク / インターフェースの環境負荷}

2000 年度, わが国の $\mathrm{CO}_{2}$ 排出量 12 億 3,700 万 ton の うち，廃棄物の焼却やセメント生産における石灰石消費 なよ゙に伴う二酸化炭素排出を除いたエネルギー起源の $\mathrm{CO}_{2}$ 排出量は, 11 億 6,000 万 ton であり, 部門別では産 業部門：4 億 9,500 万 ton, 民生部門：3 億 1,800 万 ton (家庭：1 億 6,600 万 ton, 業務： 1 億 5,200 万 ton), 運 輸部門：2 億 5,600 万 ton からの排出量が多(2)。この うち，民生，運輸部門については 1990 年度加ら $20 \%$ 以 上の伸びを示しており，増大傾向にある。政府の地球温 暖化対策推進大綱では (2002 年 3 月に改定), エネル ギー起源 $\mathrm{CO}_{2}$ 排出量等について削減目標を設けている。

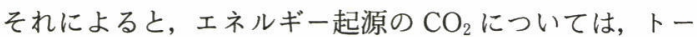

タルとして 1990 年度と同水準の排出量に抑制し, 各部 門別では 1990 年度比，産業部門で $7 \%$ 減，民生部門で $2 \%$ 减，運輸部門で $17 \%$ 增に押さえることを目標とし て掲げている。2000 年時点においてこの目標を達成す るには, エネルギー起源の $\mathrm{CO}_{2}$ 排出量全体として， 1 億 1,300 万 ton の削減が, 各部門別では, 産業部門で 3,300 万 ton，民生部門で 5,800 万 ton，運輸部門で 600 万ton の削滅が必要となっている。民生部門について は，目標を達成するために必要となる削減量が大きい一 方で，これまで排出量は大きく増加してきたことを考え ると，今後さらに対策を強化する必要がある(図 6 )。

図には, 情報通信インフラ・機器の稼動台数を推定し, 各機器の消費電力量から $\mathrm{CO}_{2}$ 排出量を試算した結果む 示した。2000 年度における, IT 機器運用時の電力消費 に起因した $\mathrm{CO}_{2}$ 排出量は 836 万 ton，その製造・輸送・ 廃棄に係わる排出量は 486 万 ton となった。運用時の

2000年度 $\mathrm{CO}_{2}$ 排出量
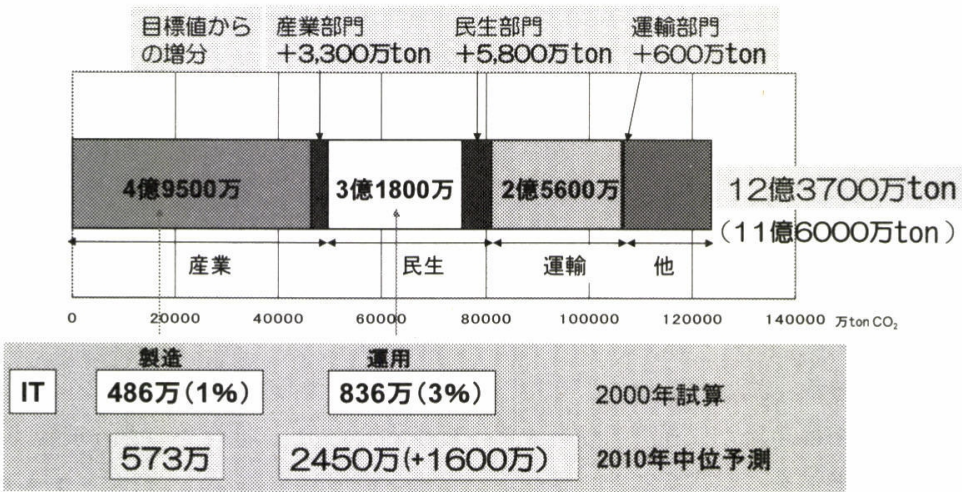

図 6 IT 機器によるエネルギー消費の増加 
排出 836 万 ton は，ほぼ民生部門（家庭・業務）にカウ ントされるため, 2000 年度での民生部門のエネルギー 起源 $\mathrm{CO}_{2}$ の排出量の内, 約 $3 \%$ IT 機器運用時の排出 が占めることとなる。IT 普及が進む 2010 年になると, 運用での排出量は 2,450 万 ton に達し (中位予測), 民 生部門からの排出量を 10 年間で約 1,600 万 ton 程度增 加させる可能性がある。2010年の予測については, 10,000 万 tonを超えるという予測もある。いずれにし ても, IT 機器普及に伴い $\mathrm{CO}_{2}$ 排出量の大きな増加が見 込まれ，その省電力化は大きな課題となる。以上は, 機 器の普及台数をべースとしたマクロな評価であるが, 現 実の固定電話網を対象とした詳細な評価む行われており， 1 加入者あたりの $\mathrm{CO}_{2}$ 排出量などが試算されている3 次に廃裹物量について考える。わが国の廃裹物量は, 一般廃裹物が約 5,000 万 ton, 産業廃裹物が約 4 億 ton 前後で推移している。IT 関連製品（プリンタ，パソコ ン, ワークステーション, ミッドレンジ・汎用コン ピュータ）の国内総廃裹量は, 現状約 14 万 ton であり (一般廃棄物の約 $0.3 \%$, 産業廃裹物の約 $0.03 \%), こ の$ 内パソコンが $50 \%$ 以上の割合を占める。今後, IT 関連 機器の普及に伴い廃裹量の増加が予想されるが, 製品の 小型化と相殺し, 2010 年での廃棄量は, 微増の約 16 万 ton と推計されている。GDPに占める IT 産業の大きさ を加味すると, $\mathrm{CO}_{2}$ 排出のインパクトと比較して, 量的 には決して大きな数字とはいえない市。

以上のような特徴より, サーバーやパソコンなどの IT 機器の LCE では, “省エネ”が重要な課題となり, 省 エネ化が進む機器については, 短期間で機器をリプレー スする“迅速循環5)”のシナリオの適用が考えられる。

\section{6. 環境配虑アプリケーション}

ライフサイクルを通して，または各段階で，環境配慮 行動に必要な情報を取得・活用するためのアプリケー ションである。各段階で必要な情報を例示すると,

1）製品製造; 部品・素材の環境配虑性, ユーザでの 使用状況, リサイクル品の供給状況など

2 ) 睴入 - 使用; 製品の環境配慮性, 使用中の環境負 荷, 適正な廃棄方法（新しい製品への代替時期, 好ましい廃裹時期・方法）など

3 ) 回収・リサイクル; 廃製品の時期・量, リサイク ル品等の需要情報など

となる。これらの情報を取得・活用する情報システムの 他に, ライフサイクルを通じた製品管理や, 環境配虑行 動に対してインセンティブを与えるための情報システム が加わる。

\section{1 使用段階における情報取得の具体例}

\section{(1) 省エネナビ6)}

一般家庭の電力消費をモニターする実験が, 省エネル ギーセンターを中心に行われている。省エネナビシステ ムは, 家庭の分電盤にモニター機器（センサー）を設置 し, 家全体の使用電力を計測し, 得られた結果を無線で 送信するというシステムである。測定した結果は, 15 分または 1 時間単位で使用量を電力料金に換算でき, 毎 月の実績値を目標値と比較したり，月の中間における電 力料金を知ったりすることができる。計測されたデー夕 は, セントラルサーバーに送信され，ユーザは，イン ターネット経由で検索ができるため, 昨年の実績值との 比較や細かい使用実態を知ることができる。

(2) エネルギー需要最適マネジメント7)

情報通信を活用して, 個別機器をネットワーク化し, 省エネルギー化を推進しようとする動きがある。これは， オフィスや家庭における各種機器をネットワーク管理し, 時間帯, 各機器の稼動状況, 周辺の環境等に応じて, 柔 軟かつ効果的な機器制御・電力供給管理を行うための技 術開発や実験が進められているものであり（HEMS : Home Energy Management System, BEMS: Building Energy Management System), その有効性む実 証されてきている。

(3) エコドライブ診断8)

運輸部門（民生分野）の二酸化炭素削減を目的に, 車 の運転によるエネルギー消費の実態と, 運転挙動（アイ ドリング, 急加速, 走行速度）とエネルギー消費の関連 を運転者に提示する実験が行われている。車に設けたセ ンサにより, 燃料噴射量, エネジン回転数, 走行速度,

スロットルポジション, エアコン on/off などの運転情 報を，無線パケット通信網によりセンターに送付する。 センターでは, 取得した運転情報を二酸化炭素排出量や 燃費情報に加工し，インターネットを通じてユーザに， 診断結果とアドバイスを提供するというシステムである。 全国 5 筒所 111 名を対象とした実験では, 平均で $5.8 \%$ の二酸化炭素削減を確認している。

\section{2 偱環型社会形成を支援する情報システムのイメージ}

情報システムの構成を, 廃製品の質・量・廃裹時期な どを管理するリサイクル QCD（Quality, Cost, Delivery）支援と，ユーザの環境行動促進支援の 2 つの機能 から考えた。

1）リサイクル $\mathrm{QCD}$ の支援

・製品の構成およびューザでの使用・廃棄状況に関 する情報のリサイクル・廃裹物業者への適切な提 供 
・使用済み製品（部品）の供給と需要情報とのマッ チング

2）ユーザの環境行動促進支援

- 製品の環境配慮性 (購入時), 適切な使用之廃棄に 関連した情報のユーザへの適切な提示

・ 環境行動に対するインセンティブ付与（グリーン マイレッジ）に関連した情報流通9)

製品に設けたユビキタス ID タグ（またはセンサー） を活用して, 製品購入時に, リサイクル容易性や安全性, 消費電力量の他製品との比較や, 販売価格の他店との比 較情報等を瞬時に表示できるシステムを実現し，環境配 慮製品の購入を促進する。使用時には, 機器のエネル ギー消費効率に関するオンライン診断，エネルギー消費 状況把握による省エネ運転支援および省エネ機器への代 替推奨などにより，使用時の消費エネルギーの削減を図 る。さらに廃棄段階では (図 7 ), リュースやリサイクル を促進するため, 回収リサイクル業者やリサイクル市場 への廃棄製品の情報提供, 機器を構成する部品・ユニッ 卜の機能, 構成素材, 有害物質含有などの情報提供を, ID タグを活用して実現する。

ID タグは，グリーンマイレッジの運用にも活用可能 である。環境配慮製品の購入, レンタル・リース品の使 用, 省エネ製品への代替, メンテナンス・修理による製 品の長期使用, リサイクル業者への製品の履歴情報の提 供や廃棄時期の告知, 回収・リサイクル容易化のための 協力なよ゙，ユーザの環境行動に対してインセンティブが 加算されるが，それを運用するために必要な情報（たと えば, 製品や部品の識別, 修理・メンテの有無, 使用期 間など）の保存に ID タグは有効であろう。

\section{7. 社会基盤アプリケーション}

米国では, 国内総生産（GDP）あたりのエネルギー 消費量が, 1997 年より低下しているが, この時期は, イン ターネットの急速な普及と一致するため, 効率向上の原 因の一つとして，インターネットによる過剩生産の削減, 移動・輸送コストの削減が考えられている。たとえば, 物流において, IT を活用することで，積載や配車の効 率化がはかれ，同一作業あたりの車の燃料消費が減ると いった効果である。また, 電子書籍や新聞が普及すれば, インターネット上でこれら印刷物を配信することで, 紙 の削減や，印刷や印刷物の運送にかかわるエネルギーの 大幅削減が生じる(脱物質化)。

書籍販売とインターネット書籍販売の比較では, イン ターネットの利用により, 物流の効率化や, 売れ残って 返品される本の減少により，本を一冊入手するまでに排 出される $\mathrm{CO}_{2}$ 排出量を，43\%削減できると試算されて いる。同様な評価が多くのアプリケーションでなされて いる ${ }^{10-13)}$ 。図 8 に，これまで実施された同様な評価を， 脱物質化システム（人や物から分離された情報だけを運 ぶ），無駄排除システム（人の移動や物の使用を適切に 管理する)，および処理効率化（既存の IT の効率化） に大別し, 各アプリケーションでの削減率をプロットし $た^{12)}$ 。

以上の評価より, IT アプリケーション導入に伴う, 資源・エネルギー効率化により $\mathrm{CO}_{2}$ 排出削減を実現で きる“場合もある”ことは明らかではあるが, 評価につ いて考慮すべき項目も多い。評価の多くは，ある地域や 使い方をモデルに試算しているが，地域等が異なれば （人口密度や交通システムなど）まったく正反対の結果 となることも起こりうる。評価が恣意的にならないよう

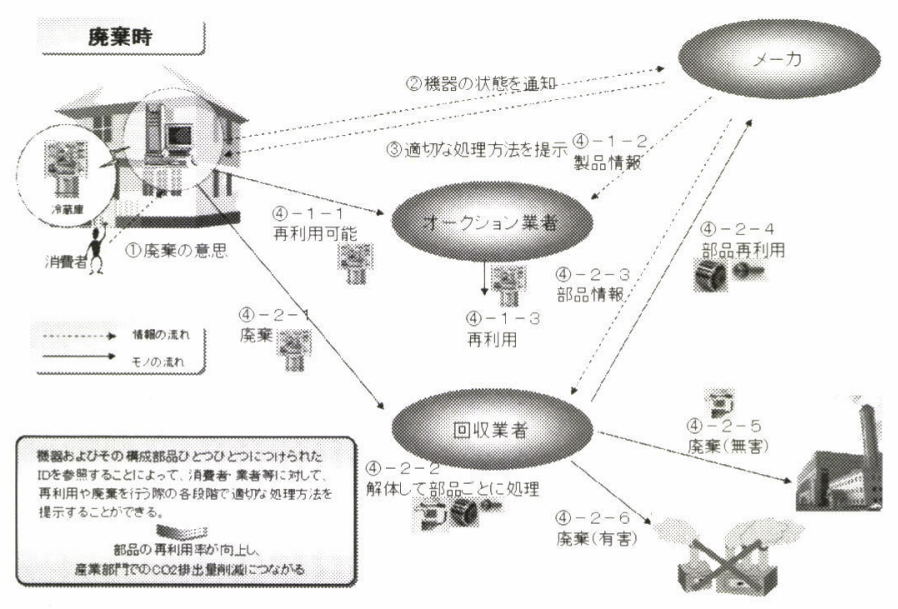

図 7 廃棄段階での RFID（Radio Freguency Identification）活用のイメージ 


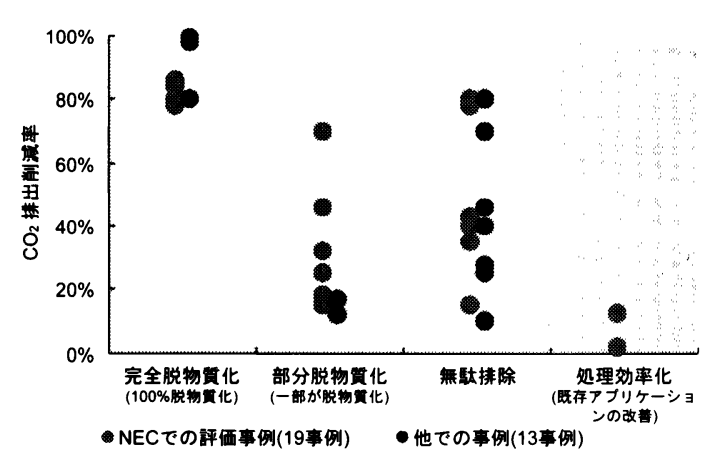

図 8 IT アプリケーションの分類と $\mathrm{CO}_{2}$ 削減率

に, モデルの一般化が重要である。また, 国によって電力 あたりの $\mathrm{CO}_{2}$ 排出量は異なるが， $1 \mathrm{kWh}$ あたりの $\mathrm{CO}_{2}$ 排出量が日本よりあ多いアジア諸国などでは, IT アプ リケーションの効果は小さなものになるであろう。効率 化により獲得した時間や資金が，新たなエネルギー消費 を生み, トータルでは $\mathrm{CO}_{2}$ 排出が増加するといった “リバウンド効果”の見積りあ大きな課題である。

\section{8. 環境調和型 IT 社会}

ネットワーク/インターフェースの環境対策 ( 5 節)， 環境配慮アプリケーション（6 節）と社会基盤アプリ ケーション（7節）の進展に伴い, 社会の環境負荷は, どのように変化する可能性があるのか。これについて， 経済モデルを利用した推定が行われている ${ }^{13)}$ 。

IT 社会のエコデザインで, 前述のマクロ評価ととも に欠かすことのできないのが, 目指すべき社会像の具体 化である。たとえば “ $\mathrm{CO}_{2}$ 排出 $1 / 2$ 社会” のイメージ を，情報通信や新エネ技術など最先端技術を活用して描 いてみる。その社会では, 高齢者も無理な移動なしに䡃 けるワークスタイル, 各人が所有しているかのように自 由に利用できる公共交通, 仕事・教育・医療等に束縛さ れない居住場所の選択（自然と共生した生活）, 資源循 環を基盤としたモノづくり，エネルギーの自由な選択な よ゙, 現在よりあ快適な生活を手に入れることが可能とな ろう。環境と経済の両立が図られたビジョンを描き, 多 くの人々と共有しながら, 各領域の技術開発（ $5 \sim 7$ 節）を進めていくことが重要である。

\section{9.おわりに}

IT が環境問題解決に与えるインパクトを, IT 社会の エコデザイン体系に基づき概説した。ITは, 環境問題 解決に大きく貢献することに疑いはない。しかし, IT
は単なる道具であるので，使い方を間違えれば逆の結果 にあなり得ることあ念頭においておく必要がある。大切 なことは，われわれが目指すべき社会の設計図を描き, そのビジョンを共有して，それに向けて各対策を進める ことである。

このような研究では, 幅広い知識の集積が必要であり, 従来の技術領域の中での垂直統合型研究（基礎一応用一 実用化）とは異なる研究スタイルを考える必要があろう。 同じ技術領域ではなく，同じ目的をあった研究者集団に よる水平統合型活動である。社会生活の質を維持しなが ら，環境負荷を低減することは確かに難しい。疾病（環 境問題）の原因である産業活動やライフスタイルを，よ り環境負荷の少ない形態に変革する原因治療的な対応が 必要だからである。IT 社会のエコデザインは, 原因治 療へ向けての第一ステップとなる。

\section{参考文献}

1) 藤本 淳, アジアェコデザイン戦略プロジェクト，東京 大学 RCAST 先端テクノロジービジネスセンター： AcTeB Review, pp.66-70 (2003)

2) http: //www.env.go.jp/earth/ondanka/taiko/

3 ) 前出利之, 折口壮史, 中村二朗, 原田大生, 天川雅丈, 宮本重幸 : 固定電話のライフサイクルアセスメント評 傮, エコデザイン 2002 ジャパンシンポジゥム (2002), pp. $16-17$.

4) (社)電子情報技術産業協会 : IT 機器の回収・処理・リサ イクルに関する調查報告書, pp. 19-27（2003）

5 ) 藤本 淳, 梅田 靖, 石田智利, 増井慶次郎, 山際康之, 小林英樹：迅速循環による地球温暖化防止の可能性の 検討 第 1 報：コンセプトと評価結果, エコデザイン 2002 ジャパンシンポジゥム講演論文集, pp. 268-271 (2002)

6) http://www.eccj.or.jp/navi/

7 ) http: //www.nedo.go.jp/kankobutsu/pamphlets/ shouene_taisaku/jyuyousaiteki.pdf

8) http://www.wanokurashi.ne.jp/kurashi/drive_m. html

9 ）(賏機械システム振興協会：リュース拡大技術に関する 研究報告書, pp. 28-30（2003）

10）三浦裕志, 白井信雄, 佐野雅之, 宮本重幸, 藤本 淳: 地球温暖化対策としての電子自治体の評価, コデザイ ン 2002 ジャパンシンポジゥム (2002), pp. 18-21.

11）中野浩介, 白井信雄, 三須崇史, 三浦裕志, 吉出信博, 山口幸儀, 加藤俊彦 : テレワークの進展による環境負 荷の削減効果に関する研究, エコデザイン 2002 ジャパ ンシンポジゥム (2002), pp. $22-25$.

12）宮本重幸, 原田大生：IT システムの環境側面を評価す る業務改善分析手法の開発，エコデザイン 2002 ジャパ ンシンポジゥム (2002), pp. 12-13.

13）エコデザイン推進機構編：エコデザイン革命——環境 とビジネスの両立—，丸善(保), pp. 34-37（2003） 


\title{
Eco-Design in an IT-Networked Society
}

\author{
Jun Fujimoto \\ Research Center for Advanced Science \& Technology, \\ the University of Tokyo \\ (4-6-1 Komaba, Meguro-ku, Tokyo, 153-8904 Japan)
}

\begin{abstract}
This paper discusses new eco-design methods developed in response to future technology demands, and their applications in a sustainable, fully-networked society. The goal of these methods and applications is to lower economic impact while at the same time reducing environmental load.

The new methods differ from conventional eco-design methods in two respects. Firstly, they attach importance to harmonizing environmental technologies with social systems. When lifestyle is integrated with technology, an image of a sustainable society that is a practical objective for the majority of the people, should be created. Once this is achieved, a social demonstration-experiment using individual targets and integrating several different kinds of technology can be conducted. The results from this experiment will be reflected in the development of new environmental technologies and policy-making decisions. This "top-down" approach is a special feature of the new methods being developed. Secondly, the new methods and applications take into consideration ways of using the functions of electrical appliances and products to reduce environmental loads. Some of these products may be very useful in reducing environmental impact. We will focus not only on the environmental loads caused by these products, but also on the benefits to the environment. We have addressed these needs in our eco-designs for a fully-networked generation.
\end{abstract}

Key words : eco-design, top-down approach, information technology, $\mathrm{CO}_{2}$ emissions, eco-life 